\title{
QUALITY OF CHARCOAL FROM THREE SPECIES OF THE Eucalyptus AND THE Corymbia citriodora SPECIES PLANTED IN THE SOUTH OF TOCANTINS
}

\author{
Raquel Marchesan ${ }^{1}$, Danyelly Nunes de Oliveira ${ }^{2}$, Renata Carvalho da Silva ${ }^{3}$, Lorrainy Azevedo de Carvalho ${ }^{2}$ \\ Rone Tavares Gomes ${ }^{4}$, Vanessa Coelho Almeida ${ }^{1}$ \\ ${ }^{1}$ Universidade Federal do Tocantins, Curso de Engenharia Florestal, Gurupi, Tocantins, Brasil - raquelmarchesan@uft.edu.br*, \\ vanessacoelhoalmeida@uft.edu.br \\ ${ }^{2}$ Engenheira Florestal, Gurupi, Tocantins, Brasil - danyelly_o@outlook.com; lorrainyac@gmail.com \\ ${ }^{3}$ Universidade Federal do Tocantins, Programa de Pós-Graduação em Engenharia Florestal, Curitiba, Paraná, Brasil - \\ renatacsilva@uft.edu.br \\ ${ }^{4}$ Universidade Federal do Tocantins, Licenciatura em Física EAD, Gurupi, Tocantins, Brasil - ronegpi@gmail.com
}

Received for publication on: 06/03/2019 - Accepted for publication on: 21/04/2020

\begin{abstract}
Resumo
Qualidade do carvão vegetal de três especiés do gênero Eucalyptus e da espécie Corymbia citriodora plantadas no sul do Tocantins. O presente estudo teve como objetivo avaliar a qualidade do carvão vegetal de três espécies do gênero Eucalyptus e da espécie Corymbia citriodora, visando a produção de energia na região Sul do estado do Tocantins. Para o estudo foi selecionado um híbrido Eucalyptus urophylla x Eucalyptus grandis e as espécies Eucalyptus urophylla, Eucalyptus camaldulensis e Corymbia citriodora. No preparo do material foram confeccionados 20 corpos de prova de cada espécie com as dimensões de 2,0 x 2,0 x 5,0 cm, sendo 10 repetições para cada marcha de carbonização com diferentes temperaturas finais e taxas de aquecimento. Foi determinada a densidade básica da madeira, rendimento gravimétrico total, rendimentos totais em gases condensáveis e não condensáveis, análise química imediata e poder calorífico superior. A espécie Corymbia citriodora apresentou maiores valores para a densidade básica da madeira $\left(0,583 \mathrm{~g} / \mathrm{cm}^{3}\right)$ e densidade aparente do carvão $\left(0,459 \mathrm{~g} / \mathrm{cm}^{3}\right)$. $\mathrm{Na} A Q I$ as espécies Eucalyptus urophylla e Corymbia citriodora apresentaram as melhores médias dentre todas as espécies. O poder calorífico variou de 7235,97 a 7573,98 (kcal/ $\mathrm{kg})$, considerado um valor aceitável para a produção energética. Recomenda-se a marcha de carbonização final de $550{ }^{\circ} \mathrm{C}$, onde as espécies de Eucalyptus urophylla e Corymbia citriodora apresentaram as melhores médias.
\end{abstract}

Palavras-chave: Marchas de carbonização; Pirólise; Análise química imediata.

\begin{abstract}
We aimed to assess the quality of charcoal from three Eucalyptus and Corymbia citriodora species for energy production in the South of Tocantins state. A hybrid Eucalyptus urophylla $\mathrm{x}$ Eucalyptus grandis, the species Eucalyptus urophylla, Eucalyptus camaldulensis, and Corymbia citriodora were selected for the study. In the preparation of the material, 20 specimens of each species with the dimensions of $2.0 \times 2.0 \times 5.0 \mathrm{~cm}$ were made, being ten repetitions for each carbonization gait with different final temperatures and heating rates. The basic wood density, total gravimetric yield, total yields in condensable and non-condensable gases, immediate chemical analysis, and higher calorific value were determined. Corymbia citriodora presented higher wood basic density $\left(0.583 \mathrm{~g} / \mathrm{cm}^{3}\right)$ and charcoal apparent density $\left(0.459 \mathrm{~g} / \mathrm{cm}^{3}\right)$. In immediate chemical analysis, Eucalyptus urophylla and Corymbia citriodora presented the best averages among all species. The calorific value ranged from 7235.97 to $7573.98(\mathrm{kcal} / \mathrm{kg})$, considered an acceptable value for energy production. The final carbonization temperature of $550^{\circ} \mathrm{C}$ is recommended, with Eucalyptus urophylla and Corymbia citriodora presenting the best averages.

Keywords: Carbonization marches; Pyrolysis; Immediate chemical analysis.
\end{abstract}

\section{INTRODUCTION}

It is estimated that forests produce $40 \%$ of all renewable energy consumed in the world (FAO, 2017). When they are used sustainably, they can provide an alternative source of fossil fuel for global energy demands (URUDDIN; FANTU, 2019). Among forest products, charcoal stands out as a substitute for mineral coal in the steel industries, where both have the functions of fuel and reducer. Charcoal is a renewable resource though, and its production can be conducted to reduce greenhouse gas emissions.

Brazil is the largest producer and consumer of charcoal in the world. According to the National Energy Balance, in 2018, 5.7 million tons of charcoal was produced. Of these, industrial consumption represented 4.9 million tons, with the pig iron, steel, and ferroalloy industries accounting for the largest consumption (4.74 million tons), which corresponds to $82.8 \%$ of all charcoal produced in the country (EPE, 2019).

FLORESTA, Curitiba, PR, v. 50, n. 3, p. 1643 - 1652, jul/set 2020.

Marchesan, R. et.al.

ISSN eletrônico 1982-4688

DOI: $10.5380 /$ rf.v50 i3. 65303 
According to IBA (2019), 91\% of charcoal consumed in 2018 was produced from planted forest wood. In line with IBGE (2018), however, the scenario is still a little different in the state of Tocantins, which is the second-largest producer of charcoal in the North of the country, where wood for energy purposes has its origin mainly in native forests. In 2018, 6,316 tons of charcoal was produced by extraction, while 140 tons were produced by forestry. The state of Tocantins was also considered the second-largest producer of firewood in the North, producing $805,512 \mathrm{~m}^{3}$ of extraction wood and $28,470 \mathrm{~m}^{3}$ of forestry wood.

Eucalyptus plantations stand out among planted forests due to their rapid growth and high productivity and, also, as an alternative to the use of native wood in the timber industries. Brazil is one of the countries with the largest areas of planted Eucalyptus forests in the world, used largely for pulp and energy production, and to a lesser extent in the sawmill sector. In Tocantins, in 2018, the area planted with Eucalyptus corresponded to 119,871 hectares (IBÁ, 2019). According to Collicchio et al. (2019), Eucalyptus wood in the state is used mainly to serve the paper and cellulose industries and the production of charcoal for steel mills, located in the states of Pará, Maranhão and Minas Gerais.

Charcoal is one of the most important by-products from wood obtained through a process known as pyrolysis, carried out in an environment in which the temperature and heating rate conditions are controlled (FROEHLICH; MOURA, 2014). The final temperature obtained and the heating speed employed in this process have a great influence on the charcoal yield and quality.

Recognizing the historical importance and potential of charcoal, this study aimed to assess the quality of charcoal from three species of the genus Eucalyptus and the species Corymbia citriodora, aiming at energy production in the South of the state of Tocantins.

\section{MATERIAL AND METHODS}

Place of study

This study was carried out at the Laboratory of Technology and Use of Forest Products at the Federal University of Tocantins, in the city of Gurupi-TO. The wood used was collected in a plantation located in the South of Tocantins, in the city of Aliança do Tocantins, located between latitude $11^{\circ} 18^{\prime} 22$ "and longitude 48 56'09". For this study, the species Eucalyptus urophylla, Eucalyptus camaldulensis, the hybrid of the crossing of Eucalyptus urophylla $\mathrm{x}$ Eucalyptus grandis and Corymbia citriodora were used at the age of eight years.

\section{Sampling}

For data collection, 20 specimens of each species were obtained, with dimensions of $2.0 \times 2.0 \times 5.0 \mathrm{~cm}$ (width $\mathrm{x}$ thickness $\mathrm{x}$ length), used in two carbonization marches with final temperatures of $500^{\circ} \mathrm{C}$ and $550^{\circ} \mathrm{C}$ (Table 1), with ten repetitions each. The 20 specimens of each species were used both for the carbonization marches and for the determination of the other properties studied.

\section{Basic density of wood}

The basic density of the wood was determined by the ratio between the dry mass and the saturated volume of each specimen, according to the standard ASTM D-2395 (ASTM, 2017).

\section{Energy properties of charcoal}

Wood pyrolysis

Before carbonization, the entire system used in the process was weighed. The charcoal was produced from the pyrolysis of the wood that was carried out in a muffle furnace with control of the final carbonization temperature, adapted for the recovery of the pyroligneous liquor. The temperature control was carried out in two different carbonization steps according to Table 1. After pyrolysis, the system was weighed again to determine the yield in charcoal, pyroligneous liquor (condensable gas), and non-condensable gases.

Table 1: Temperature and time of carbonization in function of the carbonization.

Tabela 1: Temperatura e tempo de carbonização em função da marcha de carbonização.

\begin{tabular}{|c|c|c|c|c|c|c|c|c|c|}
\hline \multirow[t]{2}{*}{ March } & \multicolumn{7}{|c|}{$\begin{array}{c}\text { Temperature } \\
\left({ }^{\circ} \mathbf{C}\right)\end{array}$} & \multirow[t]{2}{*}{$\begin{array}{l}\text { Heat Index } \\
\left({ }^{\circ} \mathbf{C} / \mathbf{m i n}\right)\end{array}$} & \multirow{2}{*}{$\begin{array}{c}\text { Time } \\
\text { (h) }\end{array}$} \\
\hline & 150 & 200 & 250 & 350 & 450 & 500 & 550 & & \\
\hline 1 & $1 \mathrm{~h}$ & $1 \mathrm{~h}$ & $1 \mathrm{~h} 30$ & $1 \mathrm{~h} 30$ & $1 \mathrm{~h}$ & $1 \mathrm{~h}$ & - & 1.19 & $7 \mathrm{~h}$ \\
\hline 2 & $1 \mathrm{~h}$ & $1 \mathrm{~h}$ & $1 \mathrm{~h} 30$ & $1 \mathrm{~h} 30$ & $30 \mathrm{~min}$ & $30 \mathrm{~min}$ & $30 \mathrm{~min}$ & 1.41 & $6 \mathrm{~h} 30$ \\
\hline
\end{tabular}

FLORESTA, Curitiba, PR, v. 50, n. 3, p. 1643 - 1652, jul/set 2020. 


\section{Charcoal apparent density}

To determine the unitary apparent density of charcoal, data on the thickness, width, and length of the charcoal were collected with the aid of a caliper with an accuracy of $0.001 \mathrm{~mm}$ to obtain the volume. To obtain the charcoal mass, the specimens were weighed on analytical scales with an accuracy of approximately $0.0001 \mathrm{~g}$. The apparent density was determined by the relationship between the weight and the volume of the coal according to Vital (1984).

Gravimetric yield on charcoal

The gravimetric yield in charcoal was calculated by the ratio between the dry mass of the charcoal produced and the dry mass of the wood used in pyrolysis, obtained by weighing on analytical scales.

Yield in pyrolytic liquor and non-condensable gases

The gravimetric yield in pyroligneous liquor was calculated by the ratio between the mass of pyroligneous liquor obtained and the dry mass of the wood used in pyrolysis, through weighing on analytical scales. The yield on non-condensable gases was calculated using Equation 1.

$$
\text { YNCG }=100-(\mathrm{YC}+\mathrm{YL})
$$

Where: $\mathrm{YNCG}=$ yield of non-condensable gases $(\%) ; \mathrm{YC}=$ yield of charcoal $(\%) ; \mathrm{YL}=$ yield of pyroligneous liquor (\%).

\section{Immediate Chemical Analysis (ICA)}

The immediate chemical analysis was determined based on the ASTM D 1762-84 standard (ASTM, 2007). The charcoal specimens, separated by species and carbonization march, were crushed and sieved. The particles that passed through the 40 mesh sieve and were retained in the 60 mesh sieve were used for AQI. To determine the content of volatile materials, the samples were sent to the muffle furnace at $850^{\circ} \mathrm{C}$ for seven minutes and weighed. To obtain the ash content and fixed carbon, the same samples were returned to the muffle furnace at $700^{\circ} \mathrm{C}$ for another 7 hours and then weighed again.

\section{Determination of the calorific value of charcoal}

The higher calorific value of coal was estimated according to Vale et al. (2002) through Equation 2.

$$
\mathrm{SHV}=4934,43+33,27 \mathrm{FC}
$$

Where: SHV = superior heat value of coal (Kcal.kg-1); FC = fixed carbon content $(\%)$.

\section{Statistical analysis}

The experimental design used was completely randomized with a $4 \times 2$ factorial arrangement, with four species and two carbonization marches, with ten repetitions each. First, the normality test was performed, which, after verification, was continued for analysis of variance (ANOVA). Observing the significant differences between the treatments, Tukey's test was used to compare the averages at a 5\% probability level. The statistical programs used for the analyses were Statgraphics Centurion XV.I and Sisvar 5.6. The program Microsoft Excel 2007® was used to calculate the Variation Coefficient (VC\%) and Pearson's correlation coefficient (R).

\section{RESULTS}

\section{Basic Density of Wood}

Table 2 shows the average basic density of the wood of the hybrid E. urophylla $\mathrm{x}$ E. grandis and $E$. urophylla, E. camaldulensis, and C. citriodora, respectively.

Table 2 - Average values of basic density of the wood of the hybrid E. urophylla $\mathrm{x}$ E. grandis and E. urophylla, E. camaldulensis, and C. citriodora.

Tabela 2 - Valores médios de densidade básica da madeira do híbrido E. urophylla x E. grandis e das espécies $E$. urophylla, E. camaldulensis e C. citriodora.

\begin{tabular}{cclc}
\hline Species & $\begin{array}{c}\text { Basic Density of Wood } \\
\left(\mathbf{g} / \mathbf{c m}^{\mathbf{3}}\right)\end{array}$ & $\begin{array}{c}\text { VC } \\
(\boldsymbol{\%})\end{array}$ & F \\
\hline E. urophylla $\times$ E. grandis & $0.465 \mathrm{c}$ & 3.83 & \\
E. urophylla & $0.531 \mathrm{~b}$ & 7.36 & \multirow{2}{*}{$77.58^{*}$} \\
E. camaldulensis & $0.512 \mathrm{~b}$ & 3.34 & \\
C. citriodora & $0.583 \mathrm{a}$ & 3.52 & \\
\hline
\end{tabular}

The averages, followed by the same lowercase letter in the column, do not differ statistically according to Tukey's test (5\%). *significant at $5 \%$ probability $(\mathrm{p}>=0.05)$

FLORESTA, Curitiba, PR, v. 50, n. 3, p. 1643 - 1652, jul/set 2020.

Marchesan, R. et.al.

ISSN eletrônico 1982-4688

DOI: $10.5380 /$ rf.v50 i3. 65303 
Regarding the basic density of the wood, there were statistically significant differences at $5 \%$ probability, in which the highest average was observed for the species $C$. citriodora with $0.583 \mathrm{~g} / \mathrm{cm}^{3}$ and the lowest average for the hybrid of crossing E. urophylla x E. grandis with $0.465 \mathrm{~g} / \mathrm{cm}^{3}$.

\section{Energetic properties of charcoal}

Wood pyrolysis

Table 3 shows the yield results of charcoal (YC charcoal), pyroligneous liquor (YL), and non-condensable gases (YNCG).

Table 3 - Total yields of the pyrolysis process for E. urophylla $x$ E. grandis hybrid and E. urophylla, E. camaldulensis, and C. citriodora.

Tabela 3 - Rendimentos totais do processo de pirólise para o híbrido E. urophylla x E. grandis e para as espécies E. urophylla, E. camaldulensis e C. citriodora.

\begin{tabular}{cccc}
\hline \multirow{2}{*}{ Species } & Parameters & \multicolumn{2}{c}{ Heating march } \\
\cline { 3 - 4 } & & $\mathbf{5 0 0}{ }^{\circ} \mathbf{C}$ & $\mathbf{5 5 0}{ }^{\circ} \mathbf{C}$ \\
\hline \multirow{3}{*}{ E. urophylla $x$ E. grandis } & YC (\%) & 31.41 & 30.81 \\
& YL (\%) & 46.59 & 47.28 \\
& YNCG (\%) & 22.00 & 21.92 \\
\hline \multirow{2}{*}{ E. urophylla } & YC (\%) & 34.78 & 35.70 \\
& YL (\%) & 41.33 & 43.30 \\
E. camaldulensis & RGC (\%) & 21.41 & 21.02 \\
& YC (\%) & 35.89 & 34.30 \\
& YL (\%) & 41.84 & 44.10 \\
& YNCG (\%) & 22.16 & 22.07 \\
\hline \multirow{2}{*}{ C. citriodora } & YC (\%) & 30.66 & 29.76 \\
& YL (\%) & 47.47 & 48.15 \\
& YNCG (\%) & 22.27 & 22.10 \\
\hline
\end{tabular}

YC coal $=$ Gravimetric yield of charcoal; $\mathrm{YL}=$ Yield of Condensable Gases $/$ pyroligneous liquor; $\mathrm{YNCG}=$ Yield of Non-Condensable Gases .

It is noted through Table 3 that the march with a final temperature of $500{ }^{\circ} \mathrm{C}$, compared to the $550^{\circ} \mathrm{C}$, provided greater gravimetric yield in charcoal, except for the species E. urophylla. In this march, among the species studied, the highest average gravimetric yield observed was for E. camaldulensis with $35.89 \%$, and the lowest average for $C$. citriodora with $30.66 \%$ (Table 3).

For the yield pyroligneous liquor, the highest average for the species $C$. citriodora at the final temperature of $550^{\circ} \mathrm{C}$ with $48.45 \%$ and the lowest average for E. urophylla at the final temperature of $500^{\circ} \mathrm{C}$ with $41.33 \%$. It is observed that species of the genus Eucalyptus spp. and the hybrid showed average values considered close for the final temperatures of $500^{\circ} \mathrm{C}$ and $550^{\circ} \mathrm{C}$. The yield in non-condensable gases varied between $21.02 \%$ and $22.27 \%$, considering the four species and the two marches (Table 3).

Charcoal apparent density

Table 4 shows the average apparent density of charcoal of the species under study submitted to the two carbonization marches. For the apparent charcoal density variable, there was a significant difference between species and between carbonization marches, in addition to the interaction between these two factors.

Table 4 - Average values of bulk density for E. urophylla x E. grandis hybrid and E. urophylla, E. camaldulensis, and $C$. citriodora species.

Tabela 4 - Valores médios de densidade aparente do carvão para o híbrido E. urophylla $x$ E. grandis e para as espécies E. urophylla, E. camaldulensis e C. citriodora 


\begin{tabular}{|c|c|c|c|c|}
\hline \multirow{2}{*}{ Parameters } & \multirow{2}{*}{ Species } & \multicolumn{2}{|c|}{ Carbonization March } & \multirow{2}{*}{$\mathbf{F}$} \\
\hline & & $500{ }^{\circ} \mathrm{C}$ & $550{ }^{\circ} \mathrm{C}$ & \\
\hline \multirow{4}{*}{ Apparent density $\left(\mathrm{g} / \mathrm{cm}^{3}\right)$} & $\begin{array}{l}\text { E. urophylla } x E . \\
\text { grandis }\end{array}$ & $\begin{array}{c}0.305 \mathrm{aD} \\
(2.93)\end{array}$ & $\begin{array}{c}0.297 \mathrm{aC} \\
(3.44)\end{array}$ & \multirow{4}{*}{$5.95^{*}$} \\
\hline & E. urophylla & $\begin{array}{c}0.393 \mathrm{aB} \\
(9.89)\end{array}$ & $\begin{array}{c}0.353 \mathrm{bB} \\
(10.99)\end{array}$ & \\
\hline & E. camaldulensis & $\begin{array}{c}0.360 \mathrm{aC} \\
(8.29)\end{array}$ & $\begin{array}{c}0.337 \mathrm{aB} \\
(4.51)\end{array}$ & \\
\hline & C. citriodora & $\begin{array}{c}0.472 \mathrm{aA} \\
(4.97)\end{array}$ & $\begin{array}{c}0.446 \mathrm{bA} \\
(5.46)\end{array}$ & \\
\hline
\end{tabular}

Averages followed by the same uppercase letter in the column and lowercase letters in the row do not differ statistically according to Tukey's test $(5 \%)$. *significant at $5 \%(01=<\mathrm{p}<0.05)$. The values between parentheses correspond to the variation coefficient $(\%)$.

For apparent charcoal density, the highest average values were obtained for the species $C$. citriodora $\left(0.472\right.$ and $\left.0.446 \mathrm{~g} / \mathrm{cm}^{3}\right)$ and the lowest average values for the hybrid E. urophylla $\mathrm{x}$ E. grandis $(0.305$ and 0.297 $\mathrm{g} / \mathrm{cm}^{3}$ ), for the carbonization marches of $500^{\circ} \mathrm{C}$ and $550^{\circ} \mathrm{C}$, respectively.

\section{Immediate chemical analysis (ICA)}

Table 5 presents average values for the content of volatile materials (\%), fixed carbon (\%) and ash (\%), for the hybrid of the cross E. urophylla x E. grandis and the species E. urophylla, E. camaldulensis and $C$. citriodora subjected to carbonization march at $500^{\circ} \mathrm{C}$ and $550^{\circ} \mathrm{C}$.

Table 5 - Average values of volatile materials (VM), fixed carbon (FC), and Ash for charcoal of the hybrid $E$. urophylla $x$ E. grandis and he species E. urophylla, E. camaldulensis, and C. citriodora.

Tabela 5 - Valores médios dos teores de materiais voláteis (MV), carbono fixo (CF) e cinzas do carvão produzido com a madeira do híbrido E. urophylla $x$ E. grandis e das espécies E. urophylla, E. camaldulensis e $C$. citriodora.

\begin{tabular}{|c|c|c|c|c|}
\hline \multirow{2}{*}{ Parameters } & \multirow{2}{*}{ Species } & \multicolumn{2}{|c|}{ Carbonization March } & \multirow{2}{*}{$\mathrm{F}$} \\
\hline & & $500{ }^{\circ} \mathrm{C}$ & $550{ }^{\circ} \mathrm{C}$ & \\
\hline \multirow{4}{*}{$\begin{array}{l}\text { Volatile charcoal materials } \\
\qquad(\%)\end{array}$} & E. urophylla $x$ E. grandis & $\begin{array}{c}30.27 \mathrm{aA} \\
(4.07)\end{array}$ & $\begin{array}{c}21.60 \mathrm{bB} \\
(3.26)\end{array}$ & \multirow{4}{*}{$23.21 *$} \\
\hline & E. urophylla & $\begin{array}{c}25.61 \mathrm{aB} \\
(5.22)\end{array}$ & $\begin{array}{c}22.96 \mathrm{bA} \\
(3.44)\end{array}$ & \\
\hline & E. camaldulensis & $\begin{array}{c}26.69 \mathrm{aB} \\
(3.60)\end{array}$ & $\begin{array}{c}22.07 \mathrm{bC} \\
(3.28)\end{array}$ & \\
\hline & C. citriodora & $\begin{array}{c}22.91 \mathrm{aC} \\
(2.46)\end{array}$ & $\begin{array}{c}19.75 \mathrm{bC} \\
(3.71)\end{array}$ & \\
\hline \multirow{4}{*}{$\begin{array}{c}\text { Charcoal fixed carbon } \\
(\%)\end{array}$} & E. urophylla $x$ E. grandis & $\begin{array}{c}69.18 \mathrm{bD} \\
(1.76)\end{array}$ & $\begin{array}{c}77.62 \mathrm{aB} \\
(0.88)\end{array}$ & \multirow{4}{*}{$24.01 *$} \\
\hline & E. urophylla & $\begin{array}{c}73.57 \mathrm{bB} \\
(1.85)\end{array}$ & $\begin{array}{c}76.22 \mathrm{aC} \\
(0.96)\end{array}$ & \\
\hline & E. camaldulensis & $\begin{array}{l}71.84 \mathrm{bC} \\
(1.16)\end{array}$ & $\begin{array}{c}76.26 \mathrm{aC} \\
(0.83)\end{array}$ & \\
\hline & C. citriodora & $\begin{array}{c}76.21 \mathrm{bA} \\
(1.14)\end{array}$ & $\begin{array}{c}79.34 \mathrm{aA} \\
(1.41)\end{array}$ & \\
\hline \multirow{4}{*}{$\begin{array}{c}\text { Charcoal ashes } \\
(\%)\end{array}$} & E. urophylla $x$ E. grandis & $\begin{array}{c}0.55 \mathrm{bC} \\
(8.60)\end{array}$ & $\begin{array}{c}0.79 \mathrm{aB} \\
(9.72)\end{array}$ & \multirow{4}{*}{$11.44 *$} \\
\hline & E. urophylla & $\begin{array}{c}0.82 \mathrm{aB} \\
(9.93)\end{array}$ & $\begin{array}{c}0.82 \mathrm{aB} \\
(9.65)\end{array}$ & \\
\hline & E. camaldulensis & $\begin{array}{l}1.47 \mathrm{aA} \\
(17.13)\end{array}$ & $\begin{array}{l}1.68 \mathrm{aA} \\
(18.04)\end{array}$ & \\
\hline & C. citriodora & $\begin{array}{c}0.88 \mathrm{aB} \\
(18.32)\end{array}$ & $\begin{array}{c}0.91 \mathrm{aB} \\
(20.31)\end{array}$ & \\
\hline
\end{tabular}

FLORESTA, Curitiba, PR, v. 50, n. 3, p. 1643 - 1652, jul/set 2020. 
Averages followed by the same uppercase letter in the column and lowercase letters in the row do not differ statistically according to Tukey's test $(5 \%)$. *significant at $5 \%(01=<\mathrm{p}<0.05)$. The values between parentheses correspond to the variation coefficient $(\%)$.

In Table 5, significant differences between species and carbonization marches are shown, as well as interaction between the two factors in all studied variables.

For the content of volatile materials, the highest average was $30.27 \%$ for the hybrid E. grandis x E. urophylla at the final temperature of $500^{\circ} \mathrm{C}$ and the lowest average was $19.75 \%$ for C. citriodora at the final temperature of $550^{\circ} \mathrm{C}$.

For the fixed carbon content of charcoal, a higher average value (79.34\%) was observed for $C$. citriodora, submitted to the final temperature of $550^{\circ} \mathrm{C}$. The lowest average value was $69.18 \%$, observed for the hybrid $E$. grandis $\mathrm{x}$ E. urophylla, when submitted to the final temperature of $500^{\circ} \mathrm{C}$.

It can be observed for the ash content that the highest average among the species was for E. camaldulensis with $1.68 \%$ at the final temperature of $550^{\circ} \mathrm{C}$ and the lowest average value observed between species was $0.55 \%$ for E. grandis x E. urophylla at the final temperature of $500^{\circ} \mathrm{C}$.

\section{Higher calorific value}

Table 6 shows the higher calorific value (HCV) for the species under study, submitted to the carbonization marches of $500^{\circ} \mathrm{C}$ and $550^{\circ} \mathrm{C}$. It can be observed that there were significant differences between species, carbonization marches, and interaction between the two factors for the studied variable.

Table 6 - Average higher calorific value (HCV) for the hybrid E. urophylla $x$ E. grandis and the species $E$. urophylla, E. camaldulensis, and C. citriodora.

Tabela 6 - Valores médios de poder calorífico superior (PCS) para o híbrido E. urophylla x E. grandis e para as espécies E. urophylla, E. camaldulensis e C. citriodora

\begin{tabular}{ccccc}
\hline \multirow{2}{*}{ Parameters } & Species & \multicolumn{2}{c}{ Carbonization March } & F \\
\cline { 3 - 4 } & E. urophyllax E. grandis & $7,235.97 \mathrm{bD}(0.56)$ & $7,516.78 \mathrm{aB}(0.30)$ \\
& E. urophylla & $7,382.04 \mathrm{bB}(0.61)$ & $7,470.11 \mathrm{aC}(0.33)$ & $37.56^{*}$ \\
Higher calorific value of & E. camaldulensis & $7,324.51 \mathrm{bC}(0.39)$ & $7,471.47 \mathrm{aC}(0.29)$ & \\
charcoal (kcal/kg) & C. citriodora & $7,469.98 \mathrm{bA}(0.37)$ & $7,573.98 \mathrm{aA}(0.48)$ & \\
\hline
\end{tabular}

$\mathrm{HCV}=$ Higher calorific value. Averages followed by the same uppercase letter in the column and lowercase letters in the row do not differ statistically according to Tukey's test $(5 \%)$. *significant at $5 \%$ probability $(01=<p<0.05)$. The values between parentheses correspond to the variation coefficient $(\%)$.

The species $C$. citriodora presented the highest average HCV among the studied species, 7,469.98 kcal $/ \mathrm{kg}$ and $7,573.98 \mathrm{kcal} / \mathrm{kg}$, in the two final carbonization temperatures of $500^{\circ} \mathrm{C}$ and $550^{\circ} \mathrm{C}$, respectively. The hybrid E. grandis $\mathrm{x}$ E. urophylla obtained the lowest average in the carbonization gait of $500^{\circ} \mathrm{C}(7235.97 \mathrm{kcal} / \mathrm{kg})$ though and the species E. urophylla and E. camaldulensis presented the lowest averages in the $550^{\circ} \mathrm{C}$ march $(7470.11$ $\mathrm{kcal} / \mathrm{kg}$ and $7471.47 \mathrm{kcal} / \mathrm{kg}$ ), respectively, which did not differ statistically.

\section{DISCUSSION}

\section{Basic Density of Wood}

One of the most relevant indicators to be evaluated among the various physical properties is the basic density of wood, considered an index for assessing quality, which may affect the others, especially the energy properties, as it interferes directly with the density of coal, its yield, and its quality. According to Silveira et al. (2013), the woods can be classified as light or low density $\left(<0.550 \mathrm{~g} / \mathrm{cm}^{3}\right)$, medium density (between 0.550 and $\left.0.720 \mathrm{~g} / \mathrm{cm}^{3}\right)$, and heavy or high-density wood $\left(>0.730 \mathrm{~g} / \mathrm{cm}^{3}\right)$. Thus, the higher the density of the wood used in the production of coal, the greater the fixed carbon content and calorific value, that is, the greater the energy potential.

Following the aforementioned classification, the average values of basic density obtained for the hybrid of the crossing of Eucalyptus urophylla $\mathrm{x}$ Eucalyptus grandis and the two species of the genus Eucalyptus spp. were low, classifying the woods as light. Thus, only the species $C$. citriodora was considered of medium basic density. The values found in our study are within the recommended in the literature for the production of goodquality charcoal (OLIVEIRA et al., 2010; JESUS et al., 2017). According to Neves et al. (2013), for the production

FLORESTA, Curitiba, PR, v. 50, n. 3, p. 1643 - 1652, jul/set 2020.

Marchesan, R. et.al.

ISSN eletrônico 1982-4688

DOI: $10.5380 /$ rf.v50 i3. 65303 
of charcoal, the higher the basic density of wood, the greater the amount of energy mass produced and the greater the mechanical resistance of charcoal.

\section{Energetic properties of charcoal}

Wood pyrolysis

Yields of charcoal and non-condensable gases decreased with the increase in the final temperature of pyrolysis, except for the yield of E. urophylla charcoal. Inverse behavior was observed for the yield of pyroligneous liquor for the hybrid and the species evaluated (Table 3 ).

According to Jesus et al. (2017), the gravimetric yield is affected by the increase in temperature and heating rate. Therefore, the higher the final temperature of the pyrolysis, the lower the yield on charcoal due to the volatilization of organic matter, consequently resulting in increased yield of pyroligneous liquor. Couto et al. (2015), however, state that high carbonization temperatures improve the chemical quality of charcoal by increasing the fixed carbon content and, hence, its calorific value. This fact was also observed in this work (Tables 5 and 6).

According to Oliveira et al. (2010), the yield in charcoal production increases considerably with the use of denser woods, resulting in better quality charcoal. This behavior was not observed in our study though, as $C$. citriodora wood showed higher basic density, lower yield of charcoal, and higher yield of pyroligneous liquor. Despite this behavior, the species presented a value considered satisfactory for use in the production of charcoal.

Jesus et al. (2017) found an average of $39.61 \%$ among their treatments for the final temperature of $380^{\circ} \mathrm{C}$. Soares et al. (2015) produced charcoal with yields of $33.06 \%$ for Eucalyptus at the age of seven years and a final temperature of $450^{\circ} \mathrm{C}$; and Oliveira et al. (2010), in a study with E. pellita charcoal, obtained averages between 31.17 and $30.88 \%$ at temperatures of 500 and $550^{\circ} \mathrm{C}$, respectively. The values presented in the literature are close to those found in our study. These values are desired in the industries, as they are superior to 30\% (JESUS et al., 2017).

All species studied showed a high yield percentage of pyroligneous liquor. Oliveira et al. (2010), in a study with E. pellita, observed averages of $58.01 \%$ and $58.09 \%$ in pyroligneous liquor for the carbonization march of 500 and $550^{\circ} \mathrm{C}$. Zanuncio et al. (2015), in a study carried out with the species $C$. citriodora and species of the genus Eucalyptus, showed average values of $31.05 \%$ for the species $C$. citriodora at the final temperature of $450^{\circ} \mathrm{C}$.

Assis et al. (2012), in a study on the quality and yield of charcoal from a hybrid clone of the crossing of E. grandis $\mathrm{x}$ E. urophylla, found average values for non-condensable gases of $28.89 \%$ at the final temperature of $450^{\circ} \mathrm{C}$. Neves et al. (2013) evaluated Eucalyptus clones in different locations aiming the production of charcoal and found values in a range of $23.67 \%$ to $26.22 \%$, at the final temperature of $450^{\circ} \mathrm{C}$.

Charcoal apparent density

With the increase in the final carbonization temperature, there was a decrease in the apparent density of the charcoal, but this reduction was only significant for the species E. urophylla and C. citriodora. A possible explanation for this fact is that the loss of mass is greater than the reduction in the dimensions of the charcoal, causing a decrease in the apparent density of charcoal. Couto et al. (2015) found, in a study carried out with clones of the genus Eucalyptus at seven years of age, an average value of $0.497 \mathrm{~g} / \mathrm{cm}^{3}$ for the species $C$. citriodora, a result close to that observed in this study.

The higher the basic density of the wood, the greater the apparent density of the charcoal. This fact, proven through the determination of Pearson's correlation coefficient (R), which corresponded to 0.906, indicated a high directly proportional correlation, that is, the increase in the basic density of the wood leads to an increase in the apparent density of the charcoal.

\section{Immediate chemical analysis (ICA) \\ Volatile material content}

The results obtained for volatile materials are favorable to the use of charcoal. The contents of volatile materials decreased with the increase in the final temperature of the pyrolysis for the hybrid and the species of the genus Eucalyptus and C. citriodora. Dias Junior et al. (2020), for samples of Eucalyptus saligna, submitted to pyrolysis at $450^{\circ} \mathrm{C}$, found the average content of volatile materials to be $29.8 \%$ and a reduction in this value with increasing temperature. Reis et al. (2013), studying E. urophylla, found an average of $26.04 \%$ for the final temperature of $450^{\circ} \mathrm{C}$.

The combustion of wood depends on its structural and non-structural chemical components. As the organic components of the wood are degraded and volatilized during pyrolysis, there is a concentration of carbon in the charcoal. Therefore, in the chemical analysis of charcoal produced at high temperatures, low levels of volatile materials, and high levels of fixed carbon are found, an essential component for the generation of thermal energy. Consequently, the slower its thermal degradation and the better its quality will be (WANG et al., 2017).

For domestic use, a carbonization march of $550^{\circ} \mathrm{C}$ is recommended for the species evaluated, as they presented acceptable values of volatile materials for energy production, with averages below $25.5 \%$, the maximum

FLORESTA, Curitiba, PR, v. 50, n. 3, p. 1643 - 1652, jul/set 2020.

Marchesan, R. et.al.

ISSN eletrônico 1982-4688

DOI: $10.5380 /$ rf.v50 i3. 65303 
value stipulated by Resolution SAA-40 (SÃO PAULO, 2015), as it determines the minimum value of $73 \%$ for the fixed carbon content and the maximum value for ash content of $1.5 \%$.

For the steel industries, a lower content of volatile materials and a higher content of fixed carbon are also desired for charcoal, as charcoal plays the role of thermal reducer, supplying carbon to remove oxygen from iron ore and fuel for energy generation (DIAS JUNIOR et al., 2020).

Fixed carbon content of charcoal

With the increase in temperature, there was a greater carbon fixation, as the content of volatile materials was lower in the carbonization march of $550^{\circ} \mathrm{C}$ when compared to the march of $500^{\circ} \mathrm{C}$. Thus, the species E. urophylla and C. citriodora can be recommended because they had lower levels of volatile materials and higher levels of fixed carbon.

Couto et al. (2015) state that, the higher the final carbonization temperature, the more intense the release of volatile materials will be. This fact will reflect on the increase in the content of inorganic compounds and fixed carbon in the solid phase during the carbonization process. Hence, carbonization marches with higher final carbonization temperatures will produce charcoal with a lower content of volatile compounds and higher levels of fixed carbon and minerals.

Oliveira et al. (2010), in a study on the influence of the final carbonization temperature, obtained average values in a range from $83.17 \%$ to $88.17 \%$. Couto et al. (2015), in a study carried out to evaluate the quality of C. citriodora charcoal, observed an average of $83.75 \%$ in the carbonization march of $550^{\circ} \mathrm{C}$, higher than the value observed in this study for the species C. citriodora. Reis et al. (2013) found average values between $71.74 \%$ and $76.93 \%$ for species of the genus Eucalyptus, considered close to those observed in this study, which comply with Resolution SAA-40 (SÃO PAULO, 2015) in the carbonization march of $550^{\circ} \mathrm{C}$, as they had fixed carbon values above $73 \%$.

The direct correlation between the fixed carbon content and volatile materials can be proven by the high calculated R-value (-0.992), which indicates that there is a high inversely proportional correlation, that is, the higher the fixed carbon content, the lower the content of volatile materials.

Ash content

The ash contents in this study were considered acceptable for the hybrid E. grandis x E. urophylla, and species E. urophylla and C. citriodora, at the final temperatures of 500 and $550^{\circ} \mathrm{C}$, respectively, as their average ash content was lower than $1.50 \%$, defined by resolution SAA-40, (2015) as ideal for good quality coal. The $E$. camaldulensis species, however, showed ash content of $1.47 \%$ and $1.68 \%$, respectively, for the final temperature of 500 and $550^{\circ} \mathrm{C}$.

Oliveira et al. (2010), in a study with E. pellita, found different values in the same carbonization marches of 500 and $550^{\circ} \mathrm{C}$, with averages of $2.19 \%$ and $2.60 \%$ respectively. Soares et al. (2015), in a study with Eucalyptus hybrids of different ages, found ash contents of $0.87 \%$ at five years of age, close to the values of this study. Jesus et al. (2017) evaluated species of the genus Eucalyptus and obtained average values in the range from $0.68 \%$ to $2.82 \%$.

It can be noted in the present study that, with the increase of the final temperature, the ash content showed an increase. Only E. urophylla showed equal values at both temperatures. The increase in ash content, with the increase in the final carbonization temperature, occurs because the inorganic chemical components remain intact, which is why they are transferred completely at temperatures below $900^{\circ} \mathrm{C}$. High levels of ash contribute to the reduction of the calorific value of charcoal, as minerals do not participate in combustion, but are determined in the fuel mass (BRAND, 2010).

High levels of ash are not desirable, especially for the use of charcoal in steel industries, as these may fuse in the walls of the boilers, causing insulation of the heating system. For domestic use, Resolution SAA-40 (SÃO PAULO, 2015) also determines a maximum value of $1.5 \%$ for the ash content. Considering this resolution as a parameter, only E. camaldulensis exceeded this value by $0.18 \%$.

\section{Higher calorific value}

The increase in calorific value is noted with the temperature variation from 500 to $550^{\circ} \mathrm{C}$. This was because the fixed carbon content was higher and the volatile material content lower at the carbonization rate of $550^{\circ} \mathrm{C}$. Brand (2010) also pointed out that the fixed and volatile carbon contents affect the calorific value. Therefore, the species E. urophylla and C. citriodora are recommended because they presented the highest average values of calorific value.

Zanuncio et al. (2015), in his study carried out for the species C. citriodora and species of the genus Eucalyptus spp., found an average value of $7545.41 \mathrm{kcal} / \mathrm{kg}$ at the final temperature of $450^{\circ} \mathrm{C}$, close to the value found for the same species in this study at the final temperature of $550^{\circ} \mathrm{C}$. Oliveira et al. (2010) presented an average of $8192.75 \mathrm{Kcal} / \mathrm{Kg}$ for E. pellita.

FLORESTA, Curitiba, PR, v. 50, n. 3, p. 1643 - 1652, jul/set 2020

Marchesan, R. et.al.

ISSN eletrônico 1982-4688

DOI: $10.5380 /$ rf.v50 i3. 65303 
Higher calorific values can be explained due to the positive correlation between the calorific value and the fixed carbon content, as confirmed by the calculated R-value (1.00), which shows a strong positive correlation between the two parameters. Charcoal with higher fixed carbon and calorific value can be used more efficiently in energy production and also as steelmaker reducers.

\section{CONCLUSION}

Through the results analyzed above, it can be concluded that:

- The physical and energetic properties of the woods of the hybrid E. urophylla $\mathrm{x}$. grandis, and the species E. urophylla, E. camaldulensis, and C. citriodora, from plantations located in the South of the state of Tocantins, meet the necessary quality standards for the production of charcoal when subject to carbonization marches with a final temperature of 500 and $550^{\circ} \mathrm{C}$.

- The carbonization marches influenced the quality of charcoal. Although the increase in the final carbonization temperature led to a reduction in the charcoal yield (except for E. urophylla), the higher temperature also provided satisfactory results, such as a reduction in the content of volatile materials and an increase in the content of fixed carbon and superior calorific value.

- According to the results obtained, it is mainly recommended to use the species Eucalyptus urophylla and Corymbia citriodora with a carbonization rate of $550^{\circ} \mathrm{C}$ because, in addition to meeting the necessary quality standards, they presented higher average values of basic wood density, apparent density of charcoal, fixed carbon content and calorific value.

\section{REFERENCES}

AMERICAN SOCIETY FOR TESTING AND MATERIALS - ASTM - D 2395: Standard Test Methods for Specific Gravity of Wood and Wood-Based Materials. Philadelphia, p.8, 2017.

AMERICAN SOCIETY FOR TESTING MATERIALS - ASTM - D 1762-84: Standard method for chemical analyses of wood charcoal. Philadelphia: ASTM International, p.2, 2007.

ASSIS, M. R. D.; PROTÁSIO, T. P.; ASSIS, C. O.; TRUGILHO, P. F.; SANTANA, W. M. S. Qualidade e rendimento do carvão vegetal de um clone híbrido de Eucalyptus grandis x Eucalyptus urophylla. Pesquisa florestal Brasileira, Colombo, PR, v. 32, n. 71, p. 291-302, jul./set. 2012.

BRAND, M. A. Energia de Biomassa Florestal. Ed. Interciência. Rio de janeiro, 2010.

COLLICCHIO, E., LOPES, R. B. S., MARCOLINI, M. de P. (2019). Análise dos possíveis efeitos das mudanças do clima no cultivo da cana-de-açúcar e do eucalipto no estado do Tocantins. Journal of Bioenergy and Food Science, 6(1), 1-17. doi: 10.18067/jbfs.v6i1.259

COUTO, A. M.; TRUGILHO, P.F. NAPOLI, A.; LIMA, J.T.; SILVA, J.R.M.; PROTÁSSIO, T.P. Qualidade do carvão vegetal de Eucalyptus e Corymbia produzido em diferentes temperaturas finais de carbonização. Scientia forestalis, Piracicaba, sp, v. 43, n. 108, p. 817-831, dez. 2015.

DIAS JUNIOR, A. F., ESTEVES, R. P., DA SILVA, Á. M. et al. Investigating the pyrolysis temperature to define the use of charcoal. Eur. J. Wood Prod. 2020, 78, 193-204.

EPE - Empresa de Pesquisa Energética (Brasil). Balanço Energético Nacional (BEN) 2019: Ano base 2018 / Empresa de Pesquisa Energética. - Rio de Janeiro: EPE, 2019. 292 p.

FAO. Forests and energy. FAO. Rome: Food and Agriculture Organisation. 2017. (Disponível em: http://www.fao.org/3/a-i6928e.pdf. Acesso em: 16/04/2020).

FROEHLICH, P. L.; MOURA, A. Carvão vegetal: propriedades físico-químicas e principais aplicações. Tecnologia e Tendências, v. 9, n. 1, jan./jun. 2014.

INSTITUTO BRASILEIRO DE GEOGRAFIA E ESTATíSTICA - IBGE. Produção da extração vegetal e da silvicultura (PEVS). Tabelas 2 e 5, Brasil, 2018. Disponível em: https://www.ibge.gov.br/estatisticas/economicas/agricultura-e-pecuaria/9105-producao-da-extracao-vegetal-eda-silvicultura.html?=\&t=resultados. Acesso em: 16/04/2020.

INDÚSTRIA BRASILEITA DE ÁRVOES - IBÁ. Relatório 2019. Brasília. v.80p. 2019.

FLORESTA, Curitiba, PR, v. 50, n. 3, p. 1643 - 1652, jul/set 2020.

Marchesan, R. et.al.

ISSN eletrônico 1982-4688

DOI: 10.5380/rf.v50 i3. 65303 
JESUS, M. S. D.; COSTA, L.J.; FERREIRA, J.C.; FREITAS, F.P.; SANTOS, L.C.; ROCHA, M.F.V. Caracterização energética de diferentes espécies de Eucalyptus. Floresta, Curitiba, PR. v. 47, n. 1, p. 11-16, jan./mar. 2017.

NEVES, T. A.; PROtÁSIO, T. P.; COUTO, A. M.; TRUGIlHO, P. F.; SIllA, V. O.; VIEIRA, C. M. M. Avaliação de clones de Eucalyptus em diferentes locais visando a produção de carvão vegetal. Pesquisa florestal brasileira, Colombo, PR, v. 31, n. 68, p. 319-330, out./dez. 2013.

OLIVEIRA, A. C.; CARNEIRO, A. C. O.; VITAL, B. R.; ALMEIDA, W.; PEREIRA, B. L. C., CARDOSO, M. T. Parâmetros da qualidade da madeira e do carvão vegetal de Eucalyptus pellita F. Muell. Scientia Forestalis, Piracicaba, SP. v. 38, n. 87, p. 431-439, set. 2010.

REIS, A. A. D.; PROTÁSSIO, T.P.; MELO, I.C.N.A; TRUGILHO, P.F.; CARNEIRO, C.O. Composição da madeira e do carvão vegetal de Eucalyptus urophylla em diferentes locais de plantio. Pesquisa florestal brasileira, Colombo, PR, v. 32, n. 71, p. 277-290, jul./set. 2013.

SILVEIRA, L. H. C.; REZENDE, A. V.; VALE, A. T. Teor de umidade e densidade básica da madeira de nove espécies comerciais amazônicas. Acta Amazônica, Manaus, v. 43, n. 2, p.179 - 184, 2013.

SÃO PAULO, Secretaria de Agricultura e Abastecimento de São Paulo. Resolução SSA - 40, de 14 de Dezembro de 2015. São Paulo, 2003. Disponível em:< http://www.codeagro.agricultura.sp.gov.br/pesquisa/saa\%2040/0/0> Acesso em: 17/04/2020.

SOARES, V. C.; BIANCHI, M.L.; TRUGILHO, P.F.; HOFLER, J.; PEREIRA, A.J. Análise das propriedades da madeira e do carvão vegetal de híbridos de Eucalyptus em três idades. Cerne, Lavras, MG. v. 21, n. 2, p. 191-197, abr./jun. 2015.

TRUGILHO, P. F., SILVA, D. A. Influência da temperatura final de carbonização nas características físicas e químicas do carvão vegetal de jatobá (Himenea courbaril L.). Scientia Agraria, v. 2, n. 1, p. 45-53, 2001.

URUDDIN, A. A.; FANTU, W. Forest Bioenergy. In: Lignocellulose for Future Bioeconomy. Elsevier, 2019. p.1-15. doi:10.1016/b978-0-12-816354-2.00001-3

VALE, A.T; ABREU, V.L.S; GONÇALEZ, J. C; COSTA, A.F. - Estimativa do Poder Calorífico Superior do Carvão Vegetal de madeiras de Eucalyptus grandis em função do Teor de Carbono Fixo e do Teor de Material Volátil. Revista Brasil Florestal, nº 73, 2002.

VITAL, B.R. Métodos de determinação de densidade da madeira. Viçosa: SIF, 1984. 21p. (Boletim técnico, 1).

ZANUNCIO, A. J. V.; CARVAlHO, A.G.; SIlVA, E.M.G.C.; MONTEIRO, T. C.; LIMA, J. T.; SILVA, J. R. M. Da. Propriedades energéticas da madeira e carvão de Corymbia e Eucalyptus em diferentes condições de secagem. Revista Brasileira de Ciências Agrárias. Recife, PE, v. 10, n. 3, p. 432-436, jan. 2015.

WANG S, DAI G, YANG H, LUO Z (2017) Lignocellulosic biomass pyrolysis mechanism: a state-of-the-art review. Prog Energy Combust Sci. 2017, p. 62, 33-86. 